\title{
共晶組成をもつ $\mathrm{Y}_{2} \mathrm{O}_{3}-\mathrm{Al}_{2} \mathrm{O}_{3}$ 系助剤添加 $\mathrm{AIN}$ セラミックスの焼結挙動と熱伝導率
}

\author{
森谷義明 ${ }^{\dagger}$ · 今村 誠·加曽利光男 · 大石克嘉 \\ 中央大学理工学部応用化学科, 112-8551 東京都文京区春日 1-13-27
}

\author{
Sintering Behavior and Thermal Conductivity of AIN Ceramics with $\mathrm{Y}_{2} \mathrm{O}_{3}-\mathrm{Al}_{2} \mathrm{O}_{3}$ \\ Additives Having Eutectic Composition
}

\author{
Yoshiaki MORIYA ${ }^{\dagger}$, Makoto IMAMURA, Mitsuo KASORI and Katsuyoshi OH-ISHI \\ Department of Applied Chemisty, Faculty of Science and Engineering, Chuo University, 1-13-27, Kasuga, Bunkyo-ku, Tokyo 112-8551
}

\begin{abstract}
We investigated sintering behavior and thermal conductivity of AIN ceramics sintered with sintering additives having the eutectic point composition $\left(a t 1760^{\circ} \mathrm{C}\right.$ ) in the phase diagram of the $\mathrm{Y}_{2} \mathrm{O}_{3}-\mathrm{Al}_{2} \mathrm{O}_{3}$ system. We used two kinds of additives, which were 2 mass $\%: \mathbf{Y}_{2} \mathrm{O}_{3}-3$ mass $\%: \mathbf{A l}_{2} \mathrm{O}_{3}$, and 4 mass $\%: \mathbf{Y}_{2} \mathrm{O}_{3}-6$ mass $\%: \mathbf{A l}_{2} \mathrm{O}_{3}$. In the sintering temperature range of $1600-1700 \mathrm{C}$, the shrinkage of the samples increased, and the formation of neck between the AIN particles progressed with the increasing temperature, while the lattice parameter $c$ of the crystal lattice in the AIN particle contracted. It was suggested that the particle growth due to the neck formation related with the contraction of the $c$ parameter although the size and shape of the AIN particle were still small and round in the temperature range. However, for the samples sintered at $1750^{\circ} \mathrm{C}$, the size and shape unexpectedly increased and became hexagonal. The sudden changes of the size and shape nearly depended on the sintering temperature almost independent of sintering time $(0.5-5 \mathrm{~h})$. The results seem to suggest an important relation between full densification of AIN and liquefaction of the sintering additives. Thermal conductivity $\lambda$ of the samples was very low value, which seems to depend on high oxygen concentration $n$ in the AIN lattice. Further, the relation between thermal resistance $(1 / \lambda)$ and the oxygen concentration $(n)$ did not strictly depend on the Slack's law for the relation for fully densified AIN ceramics. There seemed to be other factors on the low thermal conductivity.
\end{abstract}

[Received August 29, 2003; Accepted March 23, 2004]

Key-words : AlN ceramics, High thermal conductivity, Densification mechanism, Lattice parameter, Sintering additive, Al defect

1. 緒言

現在，世界的なレベルでコンピュータが普及し，それに伴う 半導体機器の製造量は増加の一途をたどっている. 半導体チッ プはLSI からできている．LSIに迅速な仕事をさせるために は，その中に流す電流の周波数を上昇させればよく，その周波 数は年々上昇している. 迅速な計算には, クロック周波数の上 昇は必須であるが，同時に，LSIの発熱量の増加と関連してい る。また，エアコン，ハイブリッドカーなどにおいては，大電 流を制御するためにパワートランジスタというチップが使用さ れている.このトランジスタを用いたLSI では, クロック周波 数はそれほどでもないが，大電流を扱うために大量の熱が発生 する．このような発熱量の上昇は, LSI の動作に対してマイナ スの効果をもっているため, 発生した熱をいかに外部に逃がす かは重要な問題である.

これを回避するために，LSI には放熱基板が必須となってい る.この放熱基板用材料のスペックとしては，1)高熱伝導性， 2)チップの材料である Si に近い熱膨張係数，3) 絶縁性が挙げ られる．この点で窒化アルミニウム（AlN）焼結体は，高性能 な放熱基板となり得る特性をもち, また，一部では実際に応用 されている11).

最初に AlN が高熱伝導率をもつことを理論的に示したの は，Slackである2)。その報告によれば，熱伝導率は $319 \mathrm{~W} /$

\footnotetext{
†現在 : 住友大阪セメント (株) 新規技術研究所, 274-8601 千葉県 船橋市豊富町 585

Now with New Technology Research Laboratory, Sumitomo Osaka Cement Co., Ltd., 585, Toyotomi-cho, Funabashi-shi, Chiba 274-8601
}

$(\mathrm{m} \cdot \mathrm{K})$ であり, また, 絶縁体の AlN が熱を伝える機構は, Al-N 結合のフォノンであると推定された。 また，AlNの熱伝 導率を低下させる要因は, AlN 粒子の結晶構造中に存在する格 子欠陥（Alの欠陥など） や不純物などであると推定された. 実際の測定值として, AlN 単結晶の熱伝導率は, $285 \mathrm{~W} / \mathrm{mK}$ で あるとの報告がある ${ }^{3)}$.

この報告に伴い, AlN 焼結体の熱伝導率も高いことが容易に 推定されたが，当時，AlNの焼結体を得るためには，高圧と高 温 $\left(2000^{\circ} \mathrm{C}\right.$ 以上) の条件が必須であった。同時に, Ponthieu $5^{4)}$ によれば，純粋な AlN 粉末の粒子は大気中の水蒸気と容易 に反応してしまい, その結果, $\mathrm{AlN}$ 粒子表面上には, $\mathrm{Al}-\mathrm{O}(\mathrm{Al}$ $(\mathrm{OH})_{3}$ や最終形態である $\left.\mathrm{Al}_{2} \mathrm{O}_{3}\right)$ という酸素を含む層が存在し ていることが分かっている.このため, 高圧-高温下での熱処 理の際，この AlN 粒子表面上に存在している $\mathrm{Al}-\mathrm{O}$ という酸化 物層が AlN 粒子の結晶格子中に拡散していき, その格子中に $\mathrm{Al}$ の欠陥が生成するため, 得られた AlN 焼結体の熱伝導率は 非常に低い值であるということも分かっている.

この問題に対して, Komeya ら ${ }^{5)}$ は AlN に希土類酸化物もし くはアルカリ土類酸化物を焼結助剂として添加することによ り，常圧下での焼結を可能にしたばかりでなく，1800 Cまで焼 結温度を低下させて AlN 焼結体を得ることに成功し, 更には, その熱伝導率をも向上させた。 その後報告された AlN 用焼結 助剤の中では, $\mathrm{Y}_{2} \mathrm{O}_{3}$ と $\mathrm{CaO}$ が最も有名な焼結助剤となった. 特に, $\mathrm{Y}_{2} \mathrm{O}_{3}$ 助剂系については, AlN の焼結過程において, 添加 した $\mathrm{Y}_{2} \mathrm{O}_{3}$ は $\mathrm{AlN}$ 粒子表面に存在する $\mathrm{Al}-\mathrm{O}\left(\mathrm{Al}_{2} \mathrm{O}_{3}\right)$ 層と反応 して $\mathrm{Y}-\mathrm{Al}-\mathrm{O}$ 系酸化物を形成すること，また，その際 $\mathrm{Y}-\mathrm{Al}-\mathrm{O}$ 系酸化物は融解し, その結果生成した液相により AlN の焼 
結が促進されるという予想が提出された. 更に, Shinozaki と Tsuge ${ }^{6)}$ や Virkar $ら^{7)}$ は, AlN の焼結過程に抢ける Y-Al-O 系 酸化物の形成は, Al-O 層が AlN 粒子の結晶格子中に拡散して いくのを防いでいるという「トラップ効果」を提唱した．この トラップ効果により, AlN 結晶格子中の $\mathrm{Al}$ の欠陥が減少し, 熱伝導率が向上するのである. その後, 熱伝導率に関しては, Ueno と Horiguchi $\left.{ }^{8}\right)$ は $\mathrm{Y}_{2} \mathrm{O}_{3}$ を焼結助剂に用いて, カーボンの セッター中 $1930^{\circ} \mathrm{C}-96 \mathrm{~h}$ という高温-長時間の熱処理をすれば, AlN 焼結体でも $260 \mathrm{~W} /(\mathrm{m} \cdot \mathrm{K})$ という熱伝導率が得られること を示した。この結果, AlN 焼結体の熱伝導率は，単結晶の熱伝 導率 $(285 \mathrm{~W} /(\mathrm{m} \cdot \mathrm{K}))$ に近づき, AlN 焼結体の応用が現実の ものとなったのである.

その後の研究の対象は，AlN 焼結体をより低温で製造する技 術を見出すことに移っていった．この研究は，AlNの低温焼結 と呼ばれている。低温焼結のコンセプトは，Y-Al-O 系酸化物 の液相が AlN の焼結を促進するという予想がもとになってい る. AlN の低温焼結に関する研究報告については, 焼結助剤と して知られている $\mathrm{Y}_{2} \mathrm{O}_{3}$ の酸素 $\left(\mathrm{O}^{2-}\right)$ をフッ素 $\left(\mathrm{F}^{-}\right)$で置換 した YOF ゃ $\mathrm{YF}_{3}$ 助剂系 ${ }^{9) \sim 13)}$ や, 3 mass $\% \mathrm{Y}_{2} \mathrm{O}_{3}-1$ mass $\% \mathrm{CaO}$ や 3 mass $\% \mathrm{Y}_{2} \mathrm{O}_{3}-1$ mass $\% \mathrm{CaO}-0.25$ mas $\% \mathrm{LaB}_{6}$ 系 ${ }^{14) \sim 19)}$ などの 研究がある.これらの文献によれば, AlN は常圧の窒素雾囲気 中 $1600^{\circ} \mathrm{C}$-数時間で完全に緻密化するところまで進んでいる. AlN の粒界で発生する焼結助剂酸化物の融解温度の変化につい ては, Shinozaki らの報告 ${ }^{20)}$ が詳しい. Shinozaki らは, 純粋な 酸化物間の相図に AlN からくる N 成分が加わると, 相図上の 液相線, 固相線は更に低下するという示唆を与えている.

しかし， $1600^{\circ} \mathrm{C}$ まで焼結温度が低下してもなお，AlN の焼結 挙動がどのような様式であるのかという点については, 種々の 議論がある. 従来から, AlN の燒結挙動は, 「液相焼結的」で あろう，という考え方はあるが，「固相焼結的」な挙動が全く ないわけではない. Horvath ら ${ }^{21}$ は, 燒結助剤を添加していな い（無添加の）場合と, 炭素を添加した場合の AlN の焼結挙 動について報告している。 その報告によれば， $1930^{\circ} \mathrm{C}-16 \mathrm{~h}$ の 焼結条件に抢いて, 助剤無添加の AlN は, その相対密度が約 90\%まで緻密化することが分かっている.

AlNの焼結挙動に関してこれまで提出された報告を見てみる と, 収縮率, 密度, $\mu \mathrm{m} レ$ ベルの走査型電子顕微鏡 $(\mathrm{SEM})$ や 透過型電子顕微鏡（TEM）観察とその結果である粒子径など の情報から，その考察を組み立てている．これら従来の結果は 非常に重要であり有用ではあるが，これからの研究においては ナノオーダーの解析結果にもとづいた微視的な考察が要求され る.

このような $\mathrm{AlN}$ の焼結挙動関する報告に対し，熱伝導率に 関しては，括おむね一致した考え方が提出されていると思われ る. Slack の考察 ${ }^{2}$ に従えば, 熱伝導率 $\lambda$ は, AlN 結晶格子中 の窒素 $\left(\mathrm{N}^{3-}\right)$ サイトに固溶した酸素 $\left(\mathrm{O}^{2-}\right)$ の量 $n$ に相関を もっているとされている. すなわち, 熱抵抗 $1 / \lambda$ は, $n$ に比例 する $\left(1 / \lambda=0.43 n+1 / \lambda_{0}\right)$. この考察については, Goto ら ${ }^{22)}$, Takada $ら^{23)}$, Watari $ら^{24)}$ が報告しているように, 窒素サイト に固溶した酸素量 $n$ が増加すると, 負のイオンが減少するの で，電気的中性則を満たすために，+3 価の電荷を持つ $\mathrm{Al}$ が 欠陥し, この $\mathrm{Al}$ 欠陥がフォノンを散乱するため, 熱伝導率が 低下すると考えられている.

その一方で, 上記報告 ${ }^{22), 23)}$ の中に記載されているもうひとつ の重要な部分は, $\mathrm{AlN}$ 結晶格子中の酸素量 $n$ が増加すると, そ の結晶格子の $c$ 軸值が減少するという, $n$ と $c$ 軸値の相関が示 されている部分である。このように, 熱伝導率に関しては, す
でに, $c$ 軸值というナノ・オングストロームレベルの測定が行 われていたことになる，その考察によれば，酸素が極めて少な い AlN 焼結体 $(260 \mathrm{~W} /(\mathrm{m} \cdot \mathrm{K})$ 材 $)$ と比較すると, 酸素量 $n$ が 多い AlN 焼結体は, $\mathrm{Al}$ の欠陥が多いと同時に, その $c$ 軸值が 小さな值であり，また熱伝導率の值も低いということになって いる. また, Harris ら ${ }^{25)}$ の結果によれば, $200 \mathrm{~W} /(\mathrm{m} \cdot \mathrm{K})$ 以上 の熱伝導率をもつ AlN 焼結体の $c$ 軸値は, その熱伝導率の上 昇に伴い大きくなることも分かっている.

ここでAlNの焼結挙動に戻って, 固相焼結のメカニズムの 中の一つに, 格子欠陥は原子拡散（焼結）を促進させるという 考え方があることに注意すると， $c$ 軸值（ $\mathrm{Al}$ の欠陥）の変化と AlN の焼結挙動の間にも相関があるではないかという推論が出 てくる．このような意味でも， $c$ 軸值の測定は重要な意味をも つと思われる. 最近, Tatami $5^{26)}$ やNakata $5^{27)}$ により, $c$ 軸 の変化と $\mathrm{AlN}$ の焼結性の相関に関する的確な報告も提出され た.

本研究の目的は, $\mathrm{Y}_{2} \mathrm{O}_{3}-\mathrm{Al}_{2} \mathrm{O}_{3}$ 相図 ${ }^{28)}$ 中の最も低温の共晶点 $\left(1760^{\circ} \mathrm{C}\right)$ である $\mathrm{Y}_{2} \mathrm{O}_{3}: \mathrm{Al}_{2} \mathrm{O}_{3}=2: 3$ mass\%の組成を, $\mathrm{AlN}$ に 焼結助剂として添加したものを試料とし, 評価方法に従来から の収縮率, 密度, SEM 観察のほかに, AIN 結晶格子の $c$ 軸值 の測定を加える.それらの結果をもとにして, AlN の焼結過程 を, 固相的部分と液相的な部分にわけて考察することにより, 少しの新たな視点を見いだすことを第一の目的としている。 た，その熱伝導率に関しても， $c$ 軸值をもとにした Slack プ ロット2)を行うことにより，その熱伝導率が粒子内の $\mathrm{Al}$ の欠 陥, もしくは粒界の状態（気孔や粒界相など）に対してどのよ うに依存しているのかについて調べることを第二の目的として いる.

\section{1 出発原料粉末の調整}

\section{2. 実 験}

(1) 焼結助剤に用いる $\mathrm{Y}_{2} \mathrm{O}_{3}$ と $\mathrm{Al}_{2} \mathrm{O}_{3}$ の 2 元系相図の $1760^{\circ} \mathrm{C}$ における共晶点温度を調査するために, $\mathrm{Y}_{2} \mathrm{O}_{3}$ 粉末（レアメタ リック, 純度 $99.99 \%$ ) と $\mathrm{Al}_{2} \mathrm{O}_{3}$ (和光純薬工業, 試薬級) の粉 末をそれぞれ指定量比 $\left(\mathrm{Y}_{2} \mathrm{O}_{3}: \mathrm{Al}_{2} \mathrm{O}_{3}=2: 3\right.$ [mass\%]）となる ように全体で $1.0 \mathrm{~g}$ 秤量した後, $\mathrm{Al}_{2} \mathrm{O}_{3}$ 製乳鉢中で乳棒を用いて $1 \mathrm{~h}$ 手動混合を行うことにより得られた酸化物混合粉末を出発 原料粉末とした.

（2）実際に上記酸化物を AlN に添加した場合における AlN の焼結挙動を調べるために, 下記に示した 2 種類の試料を調整 した.この際, 調整は, (1)及び(2)ともに AlN 粉末粒子表面に 存在する酸素量 (0.9 mass\%) を考慮した.

(1)AlN : $\mathrm{Y}_{2} \mathrm{O}_{3}: \mathrm{Al}_{2} \mathrm{O}_{3}=95: 2: 3$ [mass\%]

(2) $\mathrm{AlN}: \mathrm{Y}_{2} \mathrm{O}_{3}: \mathrm{Al}_{2} \mathrm{O}_{3}=90: 4: 6$ [mass\%]

市販の AlN 粉末（トクヤマ, F グレード，酸素量は0.9 mass\%) に, 上述の $\mathrm{Y}_{2} \mathrm{O}_{3}$ 粉末と $\mathrm{Al}_{2} \mathrm{O}_{3}$ 粉末を上記目的組成となるよう に, 全体（AIN と助剤を含めて）で50 g となるように秤量し た後, ポリポットに入れ, 溶媒としてn-ブタノール $120 \mathrm{ml}$ と $\mathrm{Al}_{2} \mathrm{O}_{3}$ 製のボールを $300 \mathrm{~g}$ を添加した.このポリポットを，回転 台上で $4 \mathrm{~h}$ 回転させることにより混合を行った．次に，ボール の除去及び, エバポレーターによる溶媒の除去の後, 目開き $212 \mu \mathrm{m}$ のふるいに通して造粒を行った。このようにして得ら れた粉末を出発原料粉末とした。

\section{2 熱処理}

(1), (2)の場合ともに, 出発原料粉末を真空デシケーター内 で $20 \mathrm{~min}$ 乾燥し, 約 $82 \mathrm{MPa}$ で錠剤型に一軸成形した. 熱処理 
前の直径を測定した後, 試料を AlN 製の鞘に入れ, またその 周囲を $\mathrm{Al}_{2} \mathrm{O}_{3}$ 製るつぼで覆った。このるつぼを黒鉛抵抗炉に入 れ，ロータリーポンプを使用して炉内部を真空にした。真空度 が $4 \mathrm{~Pa}$ 以下になったことを確認した後, 乾燥窒素ガスを充填 した. その後, 常圧下, $1 \mathrm{l} / \mathrm{min}$ の窒素ガス気流中で次の条件 で熱処理を行った.

（1）助剂として用いる酸化物混合物の共晶点温度調査の条

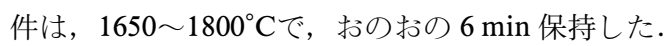

（2）実際に上記焼結助剤を添加した AlN の場合は，1600〜 $1750^{\circ} \mathrm{C}$ で， 0.5〜 $5 \mathrm{~h}$ 保持した後，炉冷した。（1)，(2)の場合と もに, 昇温速度は $10^{\circ} \mathrm{C} / \mathrm{min}$ とした。

\section{3 評価方法}

（1）熱処理後，試料全体の写真を撮影した。 また，試料の 一部を粉砕してSEMにより試料断面 (微細構造)の観察を行っ た.

（2）熱処理前と熱処理後の直径から収縮率を算出した。緻 密化が不完全な試料については，ノギス測定レベルでの密度を 概算したのに対し, 完全に緻密化した試料については, 水を溶 媒に用いたアルキメデス法により密度を測定した。

SEM により試料破断面の微構造を観察した。粉砕した試料 を XRD $\left(\mathrm{Cu} \mathrm{K} \alpha_{1}\right.$ 線 $)$ で調べることにより, 試料中の相の同定 を行うとともに，AlN 結晶格子の格子定数を算出したＡ AlN 試 料の格子定数は, 標準 Si 粉末 (リガク電機製, RSRP-43275G) を内部標準として，ステップ幅を $0.020^{\circ}$ ，サンプリング時間を $4.80 \mathrm{~s}$ で, $\operatorname{AlN} の 101^{\circ}(211), 104^{\circ}(114), 109^{\circ}(212), 111^{\circ}(105)$, $118^{\circ}(204), 125^{\circ}(300)$ の 6 本の回折ピークと標準 $\mathrm{Si}$ の $106^{\circ}(440)$, $114^{\circ}(531) の 2$ 本の回折ピークを測定した後, 最小自乗法によ り決定した.

試料の熱伝導率（ $\lambda$ ）については, 常温 $\sim 600^{\circ} \mathrm{C}$ 温度領域に おいてレーザーフラッシュ装置を用いて測定したデータを対数 法 ${ }^{29)}$ で処理することにより求めた。 また，比較のために，260 $\mathrm{W} /(\mathrm{m} \cdot \mathrm{K})$ 材と呼ばれる高熱伝導性 AlN セラミックスと完全 に緻密化させた $\mathrm{AlN}-5$ mass $\% \mathrm{Y}_{2} \mathrm{O}_{3}\left(1800^{\circ} \mathrm{C}-100 \mathrm{~min}, 1800^{\circ} \mathrm{C}-\right.$ $\left.300 \mathrm{~min}, 1800^{\circ} \mathrm{C}-1000 \mathrm{~min}\right)$ の四つの試料の熱伝導率も同様に 測定した.

\section{3. 結果と考察}

(1) $2: 3$ mass \%の比に混合した $\mathrm{Y}_{2} \mathrm{O}_{3}: \mathrm{Al}_{2} \mathrm{O}_{3}$ 混合粉末試料 ペレットを熱処理した結果を述べる. $1650^{\circ} \mathrm{C} \sim 1750^{\circ} \mathrm{C}$ の熱処理 温度では, 温度の上昇に伴い収縮率は増加したが, 試料の融解 は起こらなかった。しかし, $1800^{\circ} \mathrm{C} の$ 熱処理において試料ぺ レットは融解した。この結果から, この酸化物混合物 $\left(\mathrm{Y}_{2} \mathrm{O}_{3}-\right.$ $\mathrm{Al}_{2} \mathrm{O}_{3}=2: 3$ [mass\%]) の融解（共晶点）温度は $1750 \sim 1800^{\circ} \mathrm{C}$ の間にあることが分かり，既報の結果 $\left(\mathrm{Y}_{2} \mathrm{O}_{3}-\mathrm{Al}_{2} \mathrm{O}_{3} \text { 相図 }\right)^{28)}$ と 一致していることが確認された.

(2) XRDにより, 試料(1) ( $\mathrm{AlN}: \mathrm{Y}_{2} \mathrm{O}_{3}: \mathrm{Al}_{2} \mathrm{O}_{3}=95: 2: 3$ [mass\%]）中に AlN 以外に同定された相（以下，粒界相）は, $\mathrm{Y}_{3} \mathrm{Al}_{5} \mathrm{O}_{12}(\mathrm{YAG})$ と $\mathrm{Al}_{2} \mathrm{O}_{3}$ であった.この結果は, 前述の相 図 ${ }^{28)}$ に示されている生成物相と同一であった。これに対して, 焼結助剤を 2 倍に増やした試料(2) ( $\mathrm{AlN}: \mathrm{Y}_{2} \mathrm{O}_{3}: \mathrm{Al}_{2} \mathrm{O}_{3}=90: 4$ : $6\left[\right.$ mass \% ] ) に抢いては, $1600^{\circ} \mathrm{C}$ 以下の熱処理の場合 $\mathrm{YAG}$ と $\mathrm{Al}_{2} \mathrm{O}_{3}$ 相が同定されたが, 熱処理温度が $1650^{\circ} \mathrm{C}$ 以上の場合に は, $\mathrm{YAG}$ のほかに, $\mathrm{Al}_{3} \mathrm{O}_{3} \mathrm{~N}\left(\mathrm{Al}_{2} \mathrm{O}_{3} \cdot \mathrm{AlN}\right)^{30)}$ が同定され, 同時 に $\mathrm{Al}_{2} \mathrm{O}_{3}$ 相の回折ピークは, ほとんど消失した。本 $\mathrm{Al}_{3} \mathrm{O}_{3} \mathrm{~N}$ 相 は, McCauley らの相図 ${ }^{31)}$ 中に記載されている種々の AlON 相 と ICDD データをもとに調査した結果, 同定された。一例とし て, $1700^{\circ} \mathrm{C}-2 \mathrm{~h}$ の試料(2)の XRD パターンを図 1 に示す.ここ

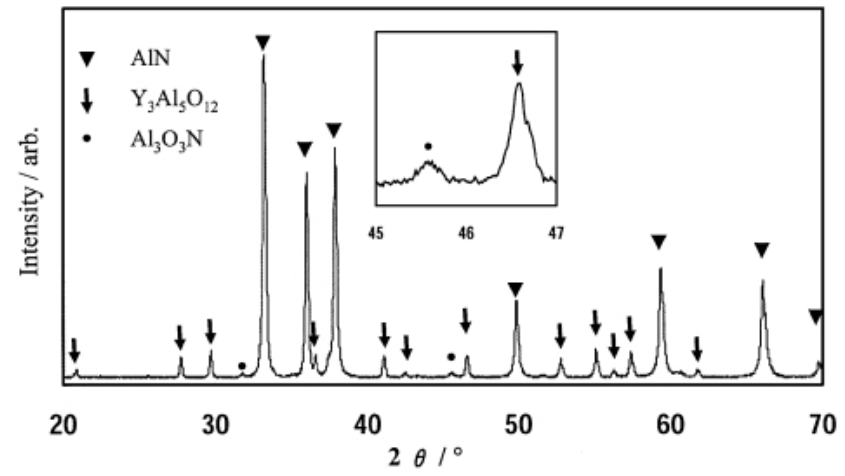

Fig. 1. X-ray diffraction pattern obtained from AlN (sample (2)) with 4 mass $\% \mathrm{Y}_{2} \mathrm{O}_{3}$ and 6 mass $\% \mathrm{Al}_{2} \mathrm{O}_{3}$ sintered at $1700^{\circ} \mathrm{C}$ for $2 \mathrm{~h}$.
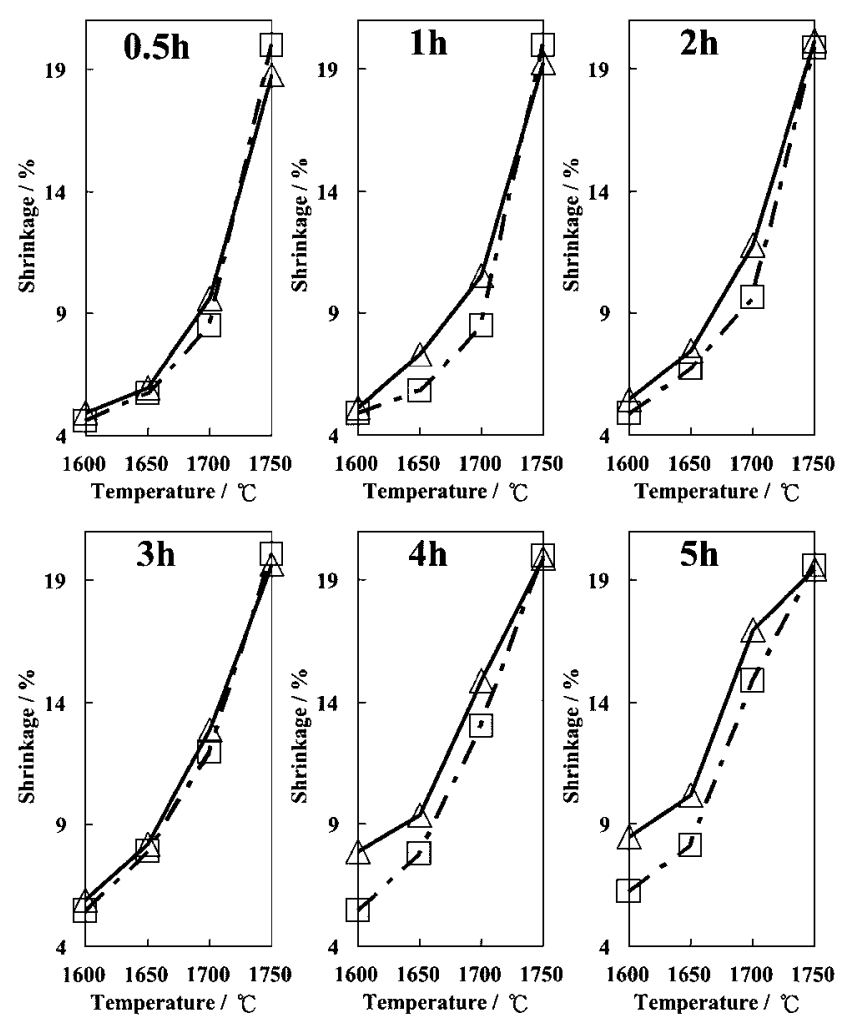

Fig. 2. Dependence of shrinkage of the sample (1) and sample (2) on the sintering Temperature and time ( $\square$ sample (1) and $\triangle$ sample (2)) .

で $\mathrm{Al}_{3} \mathrm{O}_{3} \mathrm{~N}$ の生成について考えてみる。序論でも述べたが， $\mathrm{AlN}$ の焼結過程中に打いて AlN 粒子表面や粒界に存在する $\mathrm{Al}_{2} \mathrm{O}_{3}$ 成分が, $\mathrm{AlN}$ 結晶格子中に拡散・固溶していくことやそ の固溶限界が存在することは, 既に知られている. 本試料で は，その固溶限界をゆうに超える $\mathrm{Al}_{2} \mathrm{O}_{3}$ を添加しているため， 粒界と AlN 結晶格子間の酸素濃度勾配は高い.このため, Al-O 成分は酸素の固溶が限界に達してもなお， AlN 中に拡散しよう とするはずである。おそらく，この濃度勾配が $\mathrm{AlN}$ と $\mathrm{Al}_{2} \mathrm{O}_{3}$ を直接反応させて, その中間生成物のような $\mathrm{Al}_{3} \mathrm{O}_{3} \mathrm{~N}\left(\mathrm{Al}_{2} \mathrm{O}_{3}\right.$. $\mathrm{AlN})$ を生成させるのだと考えられる. 特に, $\mathrm{Al}_{2} \mathrm{O}_{3}$ 添加量が 多い試料(2)では, XRDによりその存在が検出されるほど明ら かなのだと思われる. また, 試料(1)中にも, XRDでは検出さ れない $\mathrm{Al}_{3} \mathrm{O}_{3} \mathrm{~N}$ が存在すると予想される.

試料(1) と(2)における収縮率の熱処理温度依存性を図 2 に示 


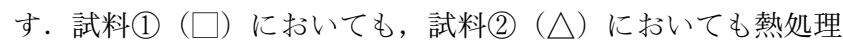
温度が上昇するにつれて, 試料の収縮率は増加した。 また, $1750^{\circ} \mathrm{C}$ で熱処理したほとんどの試料の収縮率が $20 \%$ に達した. また，熱処理時間にかかわらず，1600〜 $1700^{\circ} \mathrm{C} の$ 熱処理温度で は, 試料(1)の収縮率に比べて, 試料(2)の収縮率の方が大きい值

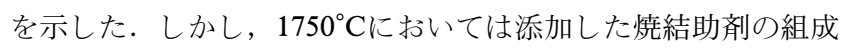
に関係なく, 試料(1)，(2)ともに，収縮率は $20 \%$ 前後の同じ值に 達した.

試料(1)の破断面の微構造（SEM）写真を図 3(a) に示す. $1600 \sim 1700^{\circ} \mathrm{C}$ では，各時間において $\mathrm{AlN}$ 粒子間のネック形成 が見られたが，大きな粒成長はあまり確認できなかった。しか し， $1750^{\circ} \mathrm{C}$ 熱処理の場合には，保持時間によらず急激に粒成 長が進行し AlN 特有の角張った形状が観察され, AlN の完全 な緻密化が示唆された。ここで, SEM 観察と密度の值を比較 してみる. $1750^{\circ} \mathrm{C} て ゙$ 熱処理した試料の密度測定の結果を保持時 間で示すと, $0.5 \mathrm{~h}$ では $3.28 \mathrm{~g} / \mathrm{cm}^{3}, 1 \mathrm{~h} \sim 2 \mathrm{~h}$ では $3.29 \mathrm{~g} / \mathrm{cm}^{3}$, $3 \mathrm{~h} \sim 5 \mathrm{~h}$ では $3.30 \mathrm{~g} / \mathrm{cm}^{3}$, であった. 密度の值は, $3 \mathrm{~h}$ 以上の場 合 $3.30 \mathrm{~g} / \mathrm{cm}^{3}$ で一定となった。この結果から, 保持時間が $0.5 \mathrm{~h}, 1 \mathrm{~h}, 2 \mathrm{~h}$ の試料の場合, SEM 写真では完全に緻密化して いるように見えるが，密度の值から見ると，緻密化は完全では ないことが分かる.これに対して, 保持時間が $3 \mathrm{~h}$ 以上の場 合, 試料は完全に緻密化しているものと思われる.

試料(2)の微細構造写真を図 3(b)に示す. 試料(2)でも，1600〜 $1700^{\circ} \mathrm{C}$ の熱処理温度では, 試料(1) と同様なネック形成が確認さ れた. $1750^{\circ} \mathrm{Cで}$ 熱処理した試料においては，どの保持時間でも 急激な粒成長が進行し角張った形状が見られた。これらの結果 を密度測定の結果と比較すると $\left(0.5 \mathrm{~h}\right.$ では $3.32 \mathrm{~g} / \mathrm{cm}^{3}, 1 \mathrm{~h}$ で は $3.34 \mathrm{~g} / \mathrm{cm}^{3}, 2 \mathrm{~h}$ では $3.35 \mathrm{~g} / \mathrm{cm}^{3}, 2 \mathrm{~h} \sim 5 \mathrm{~h}$ では $\left.3.35 \mathrm{~g} / \mathrm{cm}^{3}\right)$, これら試料が完全に緻密化するのは, 保持時間が $2 \mathrm{~h}$ 以上の場 合と思われる. 試料(1)では $3 \mathrm{~h}$ 以上で完全な緻密化が見られた が，試料(2)では $2 \mathrm{~h}$ 以上となった。助剤量が多い試料(2)の方 が, 多少緻密化しやすいという結果となった. 試料(2)密度の 值が試料(1)よりも大きい理由は, 試料(2)中には質量の大きな $\mathrm{Y}$ 成分が多く存在することによる.

試料(1)，(2)の AlN 結晶格子の $c$ 軸値の熱処理温度依存性を 図 4 に示す。各試料ともに温度の上昇につれて $\left(1600 \sim 1700^{\circ} \mathrm{C}\right.$ の温度範囲), $c$ 軸值は減少する傾向を示した. また, $c$ 軸値減 少の最低值は, 試料(1)でも(2)でもほぼ同じ值となった.このc 軸值の減少が飽和する結果は, AlN 結晶格子の窒素サイトへの 酸素の固溶が限界に達していることを示していると思われる. この限界值は, Goto $5^{22}$ や Takada $ら^{23)}$ が報告した酸素固溶限 界濃度と $c$ 軸値の関係の中の減少限界值と一致した.

前述したが， $1600 \sim 1700^{\circ} \mathrm{C}$ 温度領域では, 熱処理温度の上 昇に伴い収縮率は増加し（焼結が進行し，同時に, $c$ 軸值は減 少した.このように, 収縮率と $c$ 軸値の間には相関があること が分かる.この結果は，ごく最近の Tatami ら ${ }^{26)}$ や Nakata $5^{27)}$ の報告と全く一致するものである.

従来及び最近の報告でも言われているように22) 24),26),27), $c$ 軸 值の減少が $\mathrm{AlN}$ 結晶格子中の $\mathrm{Al}$ の欠陥の増加を示すとすれ ば, $1600^{\circ} \mathrm{C} \sim 1700^{\circ} \mathrm{C}$ 温度領域では, 温度の上昇に伴い $\mathrm{Al}$ の 欠陷が増加することになる。 また, $\mathrm{Y}_{2} \mathrm{O}_{3}: \mathrm{Al}_{2} \mathrm{O}_{3}$ 相図 ${ }^{28)}$ に従え ば, この温度領域では, 粒界相の液相は存在しないと考えられ るため, AlN の焼結の進行（収縮率の増加）は, $\mathrm{Al}$ の欠陥を 駆動力とする固相拡散に依存していると考えられる．焼結の一 般論に従って熱処理に伴い, 系 (試料) 全体が収縮して焼結が 進行する過程を, エントロピーの変化 $\Delta S$ のみで考えると, 収 縮に伴い系 (試料) の体積が減少（エントロピーが減少）する

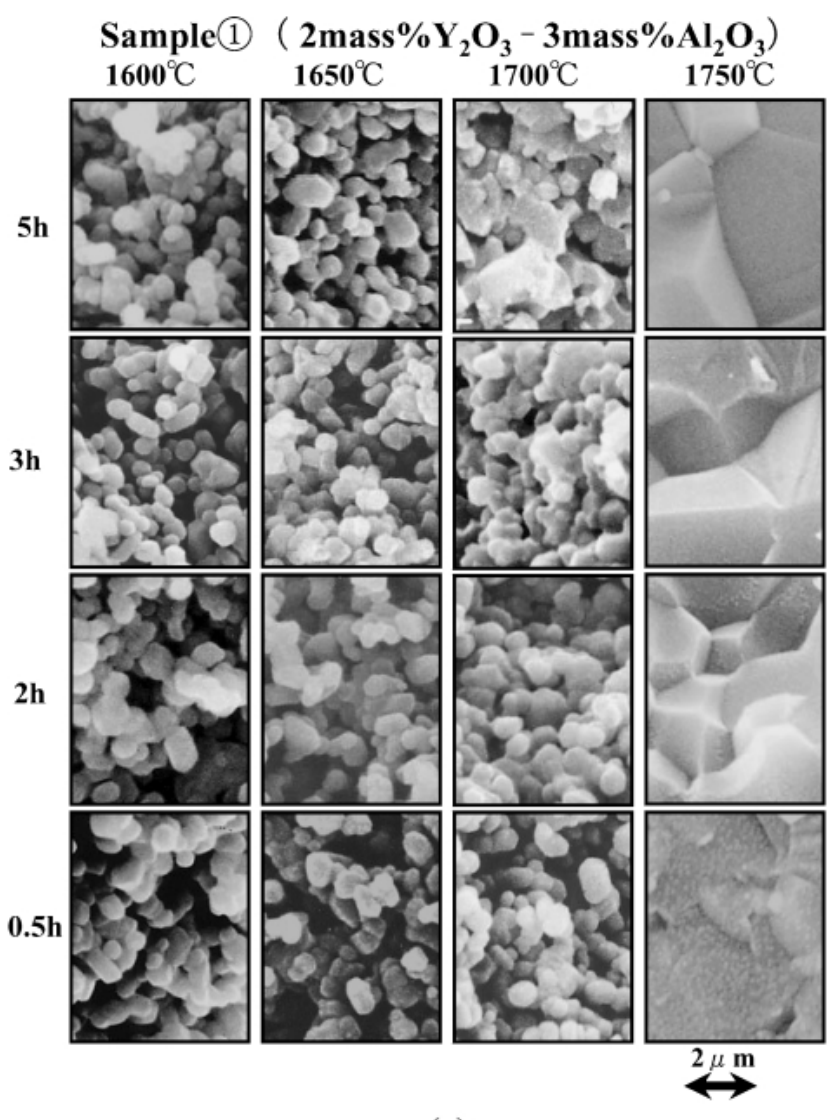

(a)

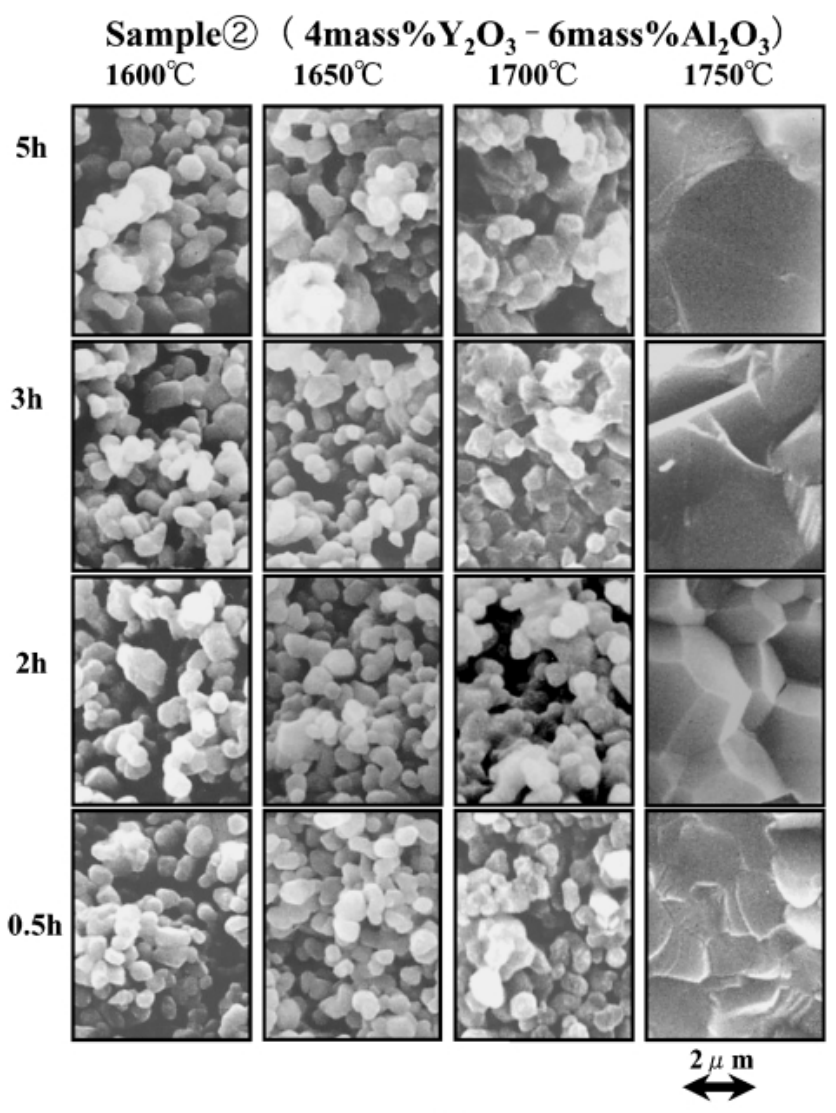

(b)

Fig. 3. (a), (b) SEM photographs obtained from the sample (1) and sample (2). 


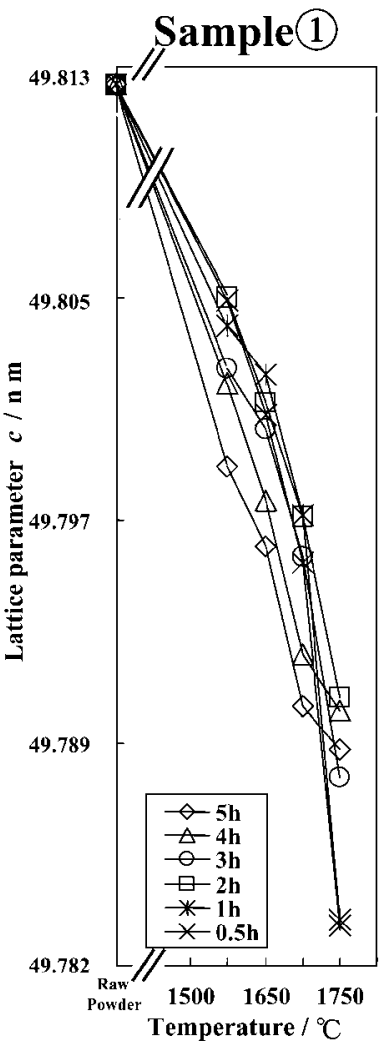

(a)

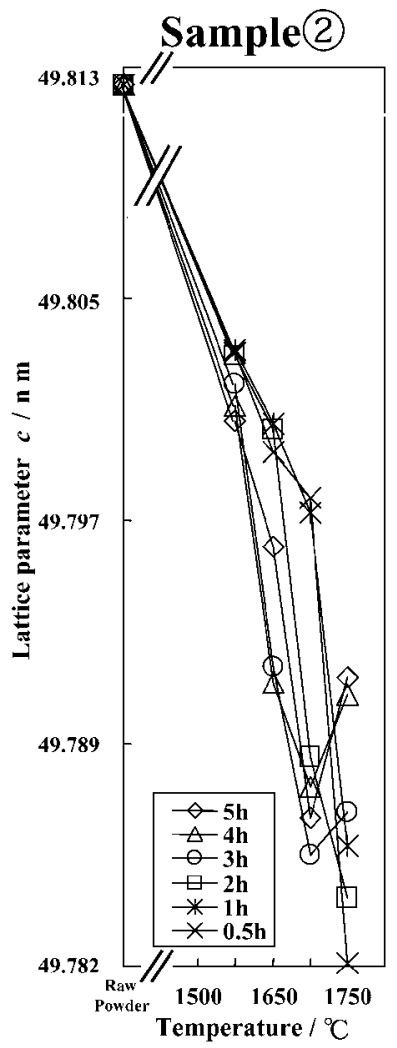

(b)
Fig. 4. Variation of lattice parameter $c$ of the sample (1) and sample (2) against sintering temperature.

ので，系はエネルギー的に不安定となり，焼結（収縮）は進行 しないはずである。しかし，エントロピーの減少によりエネル ギ一的に不安定となっても, なお焼結 (収縮) が進行するのは, 粒子間にネックが形成され粒成長が進行することにより新しい $\mathrm{AlN}$ 結晶格子が生成され, その結果この結晶格子エネルギー $\Delta H_{\text {lattice }}$ 分だけ安定化されることにより全エネルギーの変化と して安定化されるためである.このような一般論から簡単に考 慮すれば，収縮率の増加と粒子間のネック形成（粒成長）の間 には対応関係があるので, 収縮率の増加（測定值）一ネック形 成（観察図）一固相拡散（考察）という関係が成り立つと考え られる.このような考え方は, AIN の固相的焼結進行と固溶酸 素間の関係を説明するものと思われる.

これに対して, $1750^{\circ} \mathrm{C}$ での熱処理の試料において急激な粒成 長が見られたことについて考察する. 焼結助剤に用いた酸化物 混合物 $\left(\mathrm{Y}_{2} \mathrm{O}_{3}: \mathrm{Al}_{2} \mathrm{O}_{3}=2: 3[\mathrm{mass} \%]\right)$ のみの融解実験におい て, 実際の共晶点温度が $1750 \sim 1800^{\circ} \mathrm{C}$ の間に存在していること を確認した。これに付随して，それら酸化物を焼結助剤として AlN に混合した場合で $1750^{\circ} \mathrm{C}$ 熱処理のときに, AlN は急激に 粒成長した.これらの結果は, AIN の急激な緻密化と酸化物 液相の生成の間には一つの相関があることを示唆していると思 われる.

更に熱処理温度について詳細に見てみる. 酸化物混合物のみ の場合, 試料は $1750^{\circ} \mathrm{C}$ では融解せず, $1800^{\circ} \mathrm{C}$ の場合に融解し た.これに対して, 助剤を添加した $\mathrm{AlN}$ は $1750^{\circ} \mathrm{C}$ 熱処理によ り急激に粒成長した．この結果は, 酸化物が単独で融解するの は $1800^{\circ} \mathrm{C}$ 熱処理であるが，それら酸化物が $\mathrm{AlN}$ 中に存在す る場合には $50^{\circ} \mathrm{C}$ 低い $1750^{\circ} \mathrm{C}$ で融解していることを示唆している
Table 1. Thermal Conductivity $\lambda / \mathrm{W} \mathrm{m}^{-1} \mathrm{~K}^{-1}$ at $1750^{\circ} \mathrm{C}$ of the Samples with the Sintering Time

\begin{tabular}{|l|c|c|c|c|c|}
\hline & $1 \mathrm{~h}$ & $2 \mathrm{~h}$ & $3 \mathrm{~h}$ & $4 \mathrm{~h}$ & $5 \mathrm{~h}$ \\
\hline Sample (1) & 71.2 & 76.1 & 90.8 & 94.3 & 93.6 \\
\hline Sample (2) & - & - & - & 82.3 & - \\
\hline
\end{tabular}

のではないかと思われる. また，この結果は， $\mathrm{Y}_{2} \mathrm{O}_{3}-\mathrm{Al}_{2} \mathrm{O}_{3}$ 系 に AlNからく N (窒素) が混入した場合, 共晶温度がさら に低下する可能性が高いという Shinozaki ら ${ }^{20)}$ の結果 · 考察と 一致している. Shinozaki らによれば，N（窒素）の混入によ り, $\mathrm{Y}_{2} \mathrm{O}_{3}-\mathrm{Al}_{2} \mathrm{O}_{3}$ 相図中の $\mathrm{Y}_{2} \mathrm{O}_{3}: \mathrm{Al}_{2} \mathrm{O}_{3}=2: 3$ [mass\%] ( $\mathrm{YAG}$ : $\left.\mathrm{Al}_{2} \mathrm{O}_{3}\right)$ の共晶温度 $\left(1760^{\circ} \mathrm{C}\right)$ は $20^{\circ} \mathrm{C}$ 低下して, $1740^{\circ} \mathrm{C}$ となる と記述されている.これと関連して, 本研究の $\mathrm{X}$ 線回折実験 の結果から, $1650^{\circ} \mathrm{C}$ 以上の温度では試料中に $\mathrm{Al}_{3} \mathrm{O}_{3} \mathrm{~N}\left(\mathrm{Al}_{2} \mathrm{O}_{3}\right.$. $\mathrm{AlN})^{30)}$ の生成が確認されている。これらの結果は, $\mathrm{Y}_{2} \mathrm{O}_{3}$ $\mathrm{Al}_{2} \mathrm{O}_{3}-\mathrm{AlN}$ の 3 元系相図の存在を示すとともに, $\mathrm{Al}_{3} \mathrm{O}_{3} \mathrm{~N}$ 相が 共晶温度の低下に寄与していることを示唆していると思われる.

以上の結果から, AlN の緻密化の最終段階は, 酸化物液相に よる液相焼結挙動であると考えられる. その機構は, 窒化珪素 の焼結過程で見られる「溶解再析出機構」と同様な機構ではな いかと思われる.この結果は, 従来の報告の焼き直しのように 見えるが, 本研究が従来の報告と多少異なる点は, 本研究で は, 液相生成温度が一定となるように助剂酸化物添加量比を仕 込久, また, $\mathrm{Al}_{3} \mathrm{O}_{3} \mathrm{~N}$ 相の存在によりその液相生成温度が低下 している可能性を考慮したうえで, AIN の液相焼結を示唆して いる点にあると思われる.

最後に, 試料の熱伝導率 $\lambda$ の結果とその考察を示す. $1750^{\circ} \mathrm{C}$ で $1 \sim 5 \mathrm{~h}$ 熱処理した試料(1)と $1750^{\circ} \mathrm{C} て ゙ ~ 4 \mathrm{~h}$ 熱処理した試料(2)の 熱伝導率の測定值を表 1 に示す. 試料(1)の熱伝導率は, 保持時 間の増加に伴い, 多少増加傾向を示した後, $4 \mathrm{~h}$ 以上で飽和す るように見え, またどれも低い值となった。 まず, 非常に簡単 に低い熱伝導率值を説明するとすれば，その原因は，本実験で 得られた試料の $\mathrm{AlN}$ 結晶格子中の $\mathrm{Al}$ の欠陥が多い（ $c$ 軸值が 非常に短縮している）ことによると推定される.

更に詳細な考察をするために, 試料の熱伝導率を, Slack が 示した「熱抵抗 $1 / \lambda$ は, AlN 結晶格子中の固溶酸素量 $n$ に比例 する」という関係式で考えてみることにする. 試料の熱抵抗 は, 熱伝導率の逆数から得られる. 一方, 格子中の固溶酸素量 $n$ については, 今回測定した試料の $c$ 軸值を, 以前 Goto $ら^{22)}$ や Takada $5^{23)}$ が報告した「c 軸值と固溶酸素量 $n$ の関係」に 当てはめることにより概算した. 結果を図 5 に示した. 同図に はSlack が理論的に示した $1 / \lambda=0.43 n+1 / \lambda_{0}$ の直線も示してあ る.また比較のために, AlN -5 mass $\% \mathrm{Y}_{2} \mathrm{O}_{3}\left(1800^{\circ} \mathrm{C}-100 \mathrm{~min}\right.$, $\left.1800^{\circ} \mathrm{C}-300 \mathrm{~min}, 1800^{\circ} \mathrm{C}-1000 \mathrm{~min}\right)$ 及び $260 \mathrm{~W} /(\mathrm{m} \cdot \mathrm{K})$ 材と呼 ばれる高熱伝導性 AlN セラミックスの四つの試料の結果も同 時にプロットした $(\square, \triangle)$. これら試料の熱伝導率の值はそ れぞれ，170,192, 210, $253 \mathrm{~W} / \mathrm{mK}$ であった. 上記 4 試料のデー タは，打抢よそSlack の直線上に乗っていることが分かる。こ の結果は, Slackの予想どおり, 試料の熱伝導率 $\lambda$ が試料中の $\mathrm{AlN}$ 結晶格子中の酸素量 $n(\mathrm{Al}$ の欠陥量) に依存しており， $\lambda$ の值に対する粒界の関与はほとんどないことを示していると考 えられる.

これに対して, 今回の試料のデータは Slackの直線に対して 


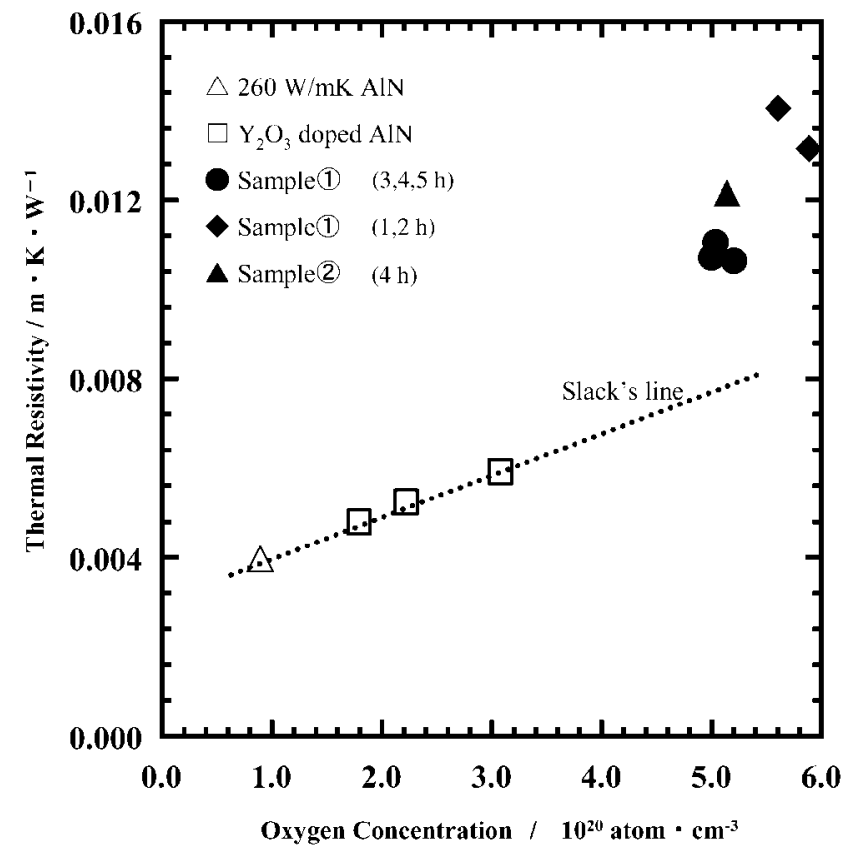

Fig. 5. Relation between thermal resistance $1 / \lambda$ and estimated oxygen concentration $n$ in AIN lattice for the samples.

上方に偏倚している．まず，完全に緻密化した試料(1) $3 \mathrm{~h}$, $4 \mathrm{~h}, 5 \mathrm{~h})$ のデータが多少上方位置にあり，その上方に試料(2) (\ $\mathrm{AlN}: \mathrm{Y}_{2} \mathrm{O}_{3}: \mathrm{Al}_{2} \mathrm{O}_{3}=90: 4: 6[\mathrm{mass} \%]$ で, $\mathrm{Al}_{3} \mathrm{O}_{3} \mathrm{~N}$ 相 ${ }^{30)}$ が 顕著である）のデータがあり，そのさらに上方に，保持時間が 短いため完全に緻密化していない試料(1)（ $1 \mathrm{~h}$ と $2 \mathrm{~h} ）$ のデー タがある.

完全に緻密化した試料(1) (3h, $4 \mathrm{~h}, 5 \mathrm{~h})$ と試料(2)の熱抵抗 $1 / \lambda$ が上方に位置する $(\lambda$ が予想より小さい) のは，拈そらく， $\mathrm{AlN}$ と $\mathrm{Al}_{2} \mathrm{O}_{3}$ の直接反応から生じた $\mathrm{Al}_{3} \mathrm{O}_{3} \mathrm{~N}$ 相が $\mathrm{AlN}-\mathrm{AlN}$ 粒 子の粒界に存在するため, $\mathrm{AlN}$ 粒子中を伝播してきたフォノン がこの相で散乱されるためと考えられる。これは， $\mathrm{Al}_{3} \mathrm{O}_{3} \mathrm{~N}$ 相 が多いと推定される試料(2)の場合, それらデータがより上方に 位置していることからも分かる. また, 更に, 試料(1) (1 h と $2 \mathrm{~h})$ において偏倚が特に大きい理由は, $\mathrm{Al}_{3} \mathrm{O}_{3} \mathrm{~N}$ 相の影響のほ かに, 緻密化が完全ではないことによる気孔の影響も重なって いるからであると思われる．Kingery ${ }^{32}$ によれば，焼結体の熱 伝導率 $\lambda$ と内部の気孔率 $\mathrm{P}$ の間に, $「 \lambda_{\mathrm{m}}=\lambda_{\mathrm{s}} \times(1-P) 」$ の関係 が知られているが $\left(\lambda_{\mathrm{m}}\right.$ は緻密化途中の試料, また， $\lambda_{\mathrm{s}}$ は完全 に緻密化した場合に対応), 本試料については, 現段階では, $\mathrm{Al}_{3} \mathrm{O}_{3} \mathrm{~N}$ 相と気孔のどちらがどれだけ熱伝導率の低下の原因で あるかについては不明であり, 今後さらなる調査が必要と思わ れる.

\section{4. まとめ}

相図上一定の液相生成温度 $\left(1760^{\circ} \mathrm{C}\right)$ をもつ $\mathrm{Y}_{2} \mathrm{O}_{3}: \mathrm{Al}_{2} \mathrm{O}_{3}=$ $2: 3$ [mass\%] を焼結助剤として添加した AlN の焼結挙動と熱 伝導率を調べた結果, 次のことが分かった.

(1) $1700^{\circ} \mathrm{C}$ 以下の熱処理温度領域では，保持時間によら ず，熱処理温度の上昇に伴い $\mathrm{AlN}$ 試料の収縮率や密度が上昇 したのに対して，AIN 結晶格子の $c$ 軸は減少した。このとき， AlN の粒径に大きな变化はなく丸い形状であったが，粒子間に ネック形成が見られた。これらの結果から，この温度領域では $\operatorname{AlN}$ の焼結は AlN 結晶格子の窒素サイトへの酸素の固溶によ
り生成する $\mathrm{Al}$ の欠陥により促進される固相拡散に依存してい ることが示唆された.

（2）熱処理温度が $1750^{\circ} \mathrm{C}$ の場合, $\operatorname{AlN}$ の粒径は急激に増加 し, AlN 特有のエッジをもつ形状となった。この温度領域に, 焼結助剂として添加した $\mathrm{Y}_{2} \mathrm{O}_{3}$ と $\mathrm{Al}_{2} \mathrm{O}_{3}(2: 3$ mass \% 比) の共 晶温度が存在することを考慮すると, AlN の焼結は, 最終的に は, 助剤酸化物の液相に依存した液相焼結過程で完了すると思 われる. その焼結機構は, 溶解再析出機構である可能性があ る.

（3）助剂酸化物が AlN 中に存在する場合, その共晶温度が 低下することが示唆された．この低下は, $\mathrm{AlN} と \mathrm{Al}_{2} \mathrm{O}_{3}$ の直接 反応から生じる $\mathrm{Al}_{3} \mathrm{O}_{3} \mathrm{~N}$ 相の生成と相関をもつと思われる.

(4) 焼結助剂として $\mathrm{Al}_{2} \mathrm{O}_{3}$ を多量に添加した試料の場合, その熱抵抗（熱伝導率の逆数）は, AlN 結晶格子中に固溶した 酸素量 $n$ に比例するというSlackの関係式には従わず, 関係式 に対して上方に偏倚することが分かった．気孔がない完全に緻 密化した試料に抢いて, この偏倚は, AlN-AlN 粒界に存在す ると思われる $\mathrm{Al}_{3} \mathrm{O}_{3} \mathrm{~N}$ 相に影響を受けていることが示唆され た. $\mathrm{Al}_{3} \mathrm{O}_{3} \mathrm{~N}$ 相は, $\mathrm{AlN}$ の焼結を促すがその一方で, 熱伝導率 を低下させる一因となることも分かった．

\section{References}

1) Werdecker, W. and Aldinger, F., IEEE Trans. Compon., Hybrids. Manuf. Technol., Vol. 7, pp. 399-404 (1984).

2) Slack, G. A., J. Phys. Chem. Solid, Vol. 34, pp. 321-335 (1973).

3) Slack, G. A. and Mcnelly, T. F., J. Cryst. Growth, Vol. 42, pp. 560-563 (1977).

4) Ponthieu, W. E., Grange, P. and Delmon, B., J. Eur. Ceram. Soc., Vol. 8, pp. 233-241 (1991).

5) Komeya, K., Inoue, H. and Tsuge, A., J. Ceram. Soc. Japan (Yogyo-Kyokai-Shi), Vol. 89, pp. 58-64 (1981).

6) Shinozaki, K. and Tsuge, A., Ceramics Japan, Vol. 21, pp. 1130-1135 (1986) [in Japanese].

7) Virker, A. F., Jackson, T. B. and Cutler, R. A., J. Am. Ceram. Soc., Vol. 72, pp. 2031-2042 (1989).

8) Ueno, F. and Horiguchi, A., Proc. 1st Europ. Soc. Conf. (ECerS'89), 1.383, 18-23 June 1989 Maastrict, The Netherlands.

9) Ueno, F., Kasori, M., Horiguchi, A. and Oh-ishi, K., Proc. of the Ann. Meet. of the Ceram. Soc. Japan (1993) pp. 1-1 [in Japanese].

10) Oh-ishi, K., Horiguchi, A., Kasori, M. and Ueno, F., Proc. of the Ann. Meet. of the Ceram. Soc. Japan (1993) pp. 2-2 [in Japanese].

11) Kasori, M., Oh-ishi, K., Horiguchi, A. and Ueno, F., Proc. of the Ann. Meet. of the Ceram. Soc. Japan (1993) pp. 3-3 [in Japanese].

12) Oh-ishi, K., Horiguchi, A., Kasori, M., Sumino, H. and Ueno, F., Proc. of 7th Fall Meet. of the Ceram. Soc. Japan (1993) pp. 125-125 [in Japanese].

13) Motoki, S., Yokota, S., Kawasaki, K., Baba, K. and Shohata, N., Proc. of the Ann. Meet. of Ceram. Soc. Japan (1991) pp. 16-16.

14) Troczynski, T. B. and Valecillos, P. S., J. Am. Ceram. Soc., Vol. 72, pp. 1488-1491 (1989).

15) Uchiyama, I. and Terao, K., Proc. of the Ann. Meet. of the Ceram. Soc. Japan (1993) pp. 5-5 [in Japanese].

16) Watari, K., Valecillos, M. C., Brito, M. B., Toriyama, M. and Kanzaki, S., J. Am. Ceram. Soc., Vol. 79, pp. 3103-3108 (1996).

17) Horiguchi, A., Kasori, M., Sumino, H. and Ueno, F., Proc. of 10th Fall Meet. on the Ceram. Soc. Japan (1997) pp. 367-367 [in Japanese].

18) Kasori, M., Sumino, H., Horiguchi, A. and Ueno, F., Ceramics 
Trans., Vol, 83, pp. 485-492 (1998).

19) Watari, K., Hwang, H. J., Toriyama, M. and Kanzaki, S., J. Mater. Res., Vol. 14, pp. 1409-1417 (1999).

20) Shinozaki, K., Sawada, Y. and Mizutani, M., Ceramics Trans., Vol. 71, pp. 307-321 (1996).

21) Horvath, S. F., Witek, S. R. and Harmer, M. P., Advances in Ceramics, Vol. 26, 18-21 (1987).

22) Goto, Y., Ueno, F., Kasori, M. and Horiguchi, A., Proc. of the Ann. Meet. of the Ceram. Soc. Japan (1990) pp. 10-10 [in Japanese].

23) Takada, K., Yonekura, I. and Ishimoto, R., Proc. of 3th Fall Meet. on the Ceram. Soc. Japan (1990) pp. 500-500 [in Japanese].

24) Watari, K., Brito, M. E., Yasuoka, M., Valecillos, M. C. and Kanzaki, S., J. Ceram. Soc. Japan, Vol. 103, pp. 891-900 (1995).
25) Harris, J. H., Brito, M. E., Yasuoka, M., Valecillos, M. C. and Kanzaki, S., J. Mater. Res., Vol. 5, pp. 1763-1773 (1990).

26) Tatami, J., Hoshiya, T., Hirata, T., Komeya, K., Meguro, T. and Tsuge, A., Ceram. Trans., in press.

27) Nakata, H., Tatami, J., Namiki, M, Komeya, K., Meguro, T., Kuibira, A. and Hotta, T., J. Ceram. Soc. Japan, Vol. 112, pp. 35-39 (2004).

28) Toropov, N. A., Bondar, I. A., Galakhov, F. Ya., Nikogosyan, X. S. and Vinogradova, N. V., Izv. Akad. Nauk SSSR, Ser. Khim., Vol. 7, pp. 1162-1162 (1964).

29) Takahashi, Y., Netsubussei, Vol. 1, pp. 3-12 (1987).

30) International Centre for Diffraction Data, ICDD, 36-50.

31) Shinozaki, K. and Tsuge, A., "Characterization of Ceramics," Ceram. Soc. Japan (1987) pp. 266-271 [in Japanese].

32) Kingery, W. D. and McQuarrie M. C., J. Am. Ceram. Soc., Vol. 37, pp. 67-72 (1954). 